\title{
Public Corporation Monopolies - Case Study of Sale of Electricity Company of Ghana (ECG)
}

\author{
Kwesi Atta Sakyi \\ B.A. (Hons.) Ghana \\ MPA (summa cum laude) UNISA \\ (Member of Oxford Round Table) \\ ZCAS University (Head-Research) \\ Dedan Kimathi Road, P.O. Box 35243, Lusaka, Zambia
}

\begin{abstract}
This essay begins by examining the theoretical economic underpinnings of different market structures, particularly state monopolies in the form of public utilities in general. The essay examines the case of the sale of the Electricity Company of Ghana (ECG) and analyses why it is being privatised. The essay examines evidence globally and holistically with review of the case for privatisation of the Electricity Company of Ghana, making suggestions for and against privatisation. The insight gained from the essay can inform other African countries (such as Zambia) which are contemplating the sale of their public utilities. The main arguments used for maintaining state monopolies is that they create massive jobs for the people and help the poor access public services cheaply, thereby narrowing the income gap. On the other hand, the main arguments against the continued maintenance of state enterprises is that they are inefficiently run, and they account for the bulk of external public debt of poor countries. Besides, they have been held to ransom by a few politicians and their cohorts whereby these state enterprises are used as conduit pipes for siphoning state funds into the pockets of a few people in privileged political positions. Some of these state monopolies harbour political cadres, failed politicians, and ghost workers. The Washington Consensus and the Bretton Woods institutions which are some of the credible creditors to many African countries have over the years called upon many heavily- indebted African countries to reform and align their loss-making institutions, hence the sale of many of the public institutions such as the Electricity Company of Ghana(ECG). To many an unlettered African, the sale of public utilities is seen as an act of abomination, an unpatriotic act, and a politically-motivated move. It is the objective of this essay to debunk these faulty theses or premises and lay bare the facts.
\end{abstract}

Key words: public utility, state-owned enterprise, public corporation, energy, electricity, privatisation, denationalisation, rationalisation, efficiency, state monopoly. ECG, market structures, divestiture

\section{INTRODUCTION}

This research project examines the issue of market monopoly by a state monopoly in Ghana, specifically the Electricity Company of Ghana (ECG) which is billed to be sold to a consortium of foreign owners led by the Manila Power Company of the Philippines. The essay will contain a review and reflection of the Managerial Economics topics tackled in the Managerial Economics course namely Demand and Elasticity, Supply and Market Equilibrium, Economic Efficiency, and Pricing mechanisms under different market structures namely Perfect Competition, Monopoly, Oligopoly, Oligopsony, and Monopsony, Monopolistic Competition, Contestable markets, and Missing Markets. 
The essay will trace through the global debate outlining the trends on Public Corporations or Parastatals or State-Owned Enterprises (SOEs), and discuss the rationale for offloading these loss-making state monopolies through Divestiture, Liquidation, and Privatisation. Insights gained in the review of the literature will lead to making recommendations based on global best practices, principles, and standards. Finally, issues of Ethics and Diversity in the privatisation of ECG will be explored.

The writer will show the significance of the study to himself and to other stakeholders, especially to those in his home country Ghana where many people make uninformed statements about government policy decisions which they perceive to be based on political leanings and inclinations. This state of ignorance leads to conjectures, wild speculations, rumour-mongering, hearsay and fake news on social media.

\section{Demand and Elasticity}

\section{REVIEW AND REFLECTION OF MANAGERIAL ECONOMICS}

Demand in economics means effective demand or demand backed by ability to pay. Demand represents the manifest need for goods and services by consumers which is depicted by a downward sloping demand curve establishing an inverse or indirect relationship between price and quantity demanded. Underlying the demand function is the marginal utility of consumers which shows their additional satisfaction derived from consuming an additional unit of a good. The more elastic demand is, the less producers can exploit consumers. In the perfect competitive market, producers face an infinitely elastic demand curve, which makes them price-takers.

Elasticity of demand affects the pricing decisions of market players as when demand is elastic, producers are likely to lower price in order to sell more and make profit by volume sales. On the other hand, monopolists tend to increase price because they are price-makers and they face an inelastic demand curve as their goods have few substitutes. In economics, we have concepts of unit elasticity, cross elasticity, and income elasticity. Basically, elasticity is calculated as percentage change in quantity demanded or supplied divided by percentage change in price. There is point elasticity and arc elasticity.

\section{Supply and Market Equilibrium}

Supply in economics represents the quantity of goods and services brought to the market by the prevailing market price. Supply does not reflect the entire output available. Thus we have short term, medium term, and long term supply curves. The short term supply curve is inelastic because of time and technological constraints. The short run supply curve is inelastic because it takes time to organise further resources.

Market equilibrium in a perfect market settles at the point where demand equals supply, and the market is cleared. Price determination through free interaction of the forces of supply and demand is referred to as the invisible hand of the market while government intervention through price controls and granting of subsidies are referred to as visible hand of the market.

\section{Economic Efficiency}

Economic efficiency is also referred to as Pareto optimality or Allocative Efficiency whereby maximum use is made of all resources available such that for a change to be made optimal, it should at least make one person better off and none worse off (businessdictionary.com). 


\section{Pricing}

Price is the exchange value of a good or service or what a customer deems the worth of an item in terms of its utility. There are different ways of determining price based upon the type of market structure or level of competition present in the market.

\section{Cost-plus Pricing}

Cost-plus pricing is based on the unit cost of production or Average Cost (AC) which is a sum of Average Variable Cost (AVC) and Average Fixed Cost (AFC). Cost-plus pricing is more typical of imperfect markets with considerable entry barriers than that found in perfect markets.

\section{Marginal cost Pricing}

Marginal cost pricing is found in all types of markets because they all follow the golden rule of setting MR = MC. If a firm has to set price below MC, it will shut down. The part of the MC curve above the price line becomes the effective supply curve of the firm. The monopolist tends to engage in marginal cost pricing because he is a profit maximizer and a price maker.

\section{Penetration Pricing}

Penetration pricing is low price adopted by a new entrant to a market as a pricing strategy in order to capture some market share from existing market players.

\section{Price Skimming}

Price skimming is a pricing strategy whereby at the initial entry of a novel product to a market, the producer chooses to set a very high price in order to recover sunk cost very fast but as new entrants enter the market to compete, he starts to reduce the price.

\section{Transfer Pricing}

Transfer pricing is a strategy which Multinationals (MNCs) with subsidiaries in many places around the globe use to transfer some of their costs in a high cost country to a low cost country so that they can post lower costs and be able to compete favourably.

\section{Premium Pricing}

Premium pricing is whereby a firm sets high price for its products because it is branded and differentiated as a superior product.

\section{Mark-up Pricing}

Mark-up pricing is undertaken by wholesalers and retailers who are not producers but intermediaries in the supply chain. Mark-ups range from about 5 per cent up to about 25 per cent.

\section{Going market price}

Oligopolies tend to engage in price-leadership, dominant- price leadership, and barometric price leadership as there is mutual interdependence, market instability, and uncertainty among the few large players who may engage in collusion and non-collusion depending on market contextual factors. Thus, oligopolists follow the market going price.

\section{TYPES OF COMPETITION}

By using the Hirschman-Herfindahl Index (HHI) we can calculate the type of market structure by summing the squares of the largest 50 firms. If the result is zero, then we have a situation of perfect competition. If the result is 2,500 (25\% market share) and above, up to $10,000,(100 \%)$ then we have a monopoly market. 


\section{Perfect Competition}

A perfect market is impersonal because no one individual can by their action influence market conditions and as such no abnormal profits are made in the long run.

The long run equilibrium in a perfect market occurs

Where, $\mathrm{AR}=\mathrm{AC}=\mathrm{P}=\mathrm{D}=\mathrm{MR}=\mathrm{MC}$.

Each firm chooses the output they want but have to sell at market prevailing price. All the players are price-takers Corn farmers are in perfect competitive markets but they buy farm inputs such as fertilizers and machinery from Oligopolistic markets.

- In a perfect market, no abnormal profits exist so consumers have a better deal.

- Producers are free to enter or exit

- Consumers are not cheated or exploited because of free access to information

- Producers can produce as much as they want and sell at the prevailing market price

- There is no price discrimination as products are homogenous.

\section{Disadvantages}

- Absence of abnormal profits means firms cannot have excess internal funds to plough back for expansion

- Consumers cannot show off their wealth by buying exclusive premium products

\section{Sources of Monopoly Power}

- Control over natural resources such as metals

- Control over patents, proprietary licences, and processes (Microsoft, Apple, Samsung, and Huawei, for example)

- Natural monopolies that emerge after a price war, mergers and acquisitions

- National strategic monopolies such as public utilities which are legal or statutory monopolies

- Sole market franchise granted to a dealer e.g. Toyota dealer in South Africa

- Examples of Legal monopolies which are set up by Acts of Parliament are ESKOM, ZESCO, ECG (power utilities in S.A., Zambia, and Ghana respectively)

\section{Monopoly Power and Existing Anti-Trust Laws in USA}

- Sherman Act of 1890

- Clayton Act of

- Packers and Stockers Act of 1921

- Capper-Volstead Act of 1922

- Robinson Packman Act

- Sarbanes-Oxley Act of 2002

- Through price controls such as Minimum price control (Price floors) and Maximum Price Control (Price Ceilings) and Anti-Trust or Anti-Monopoly Law such as 1890 Sherman Act, monopoly power can be controlled.

Microsoft at one time was asked to demerge but they won their court case. The Federal Justice Department and Competition Commission have oversight over monopolies. Monopolies can be checked through Take-overs and nationalization and through setting up rival firms which are supported by governement subsidies.

In Africa, poverty levels are high, necessitating government interventions in the free market by establishing public-owned corporations and utilities such as electricity generation and 
transmission entities such as ESKOM in South Africa, NEPA in Nigeria, ZESCO in Zambia, and ECG in Ghana.'

Many Water and Sewerage companies, railway rolling stock and systems, universities, and hospitals belong to governments. These entities were established by Acts of Parliament and funded, managed, and controlled by governments. They provide goods and services at minimum cost to majority of the poor people. They help bridge wide income gaps between the rich and poor, thus helping to alleviate poverty. They create many jobs for many graduates.

'They also avoid fragmentation of essential services by the private sector and they provide strategic services in the national interest to prevent control of the economy by foreigners. However, they are poorly managed and politicized with a lot of incompetence, leading to shoddy services and heavy financial losses.

Lack of competition leads to inefficiency and sub-standard goods and services being served toconsumers.

Government may not have enough capital to run and maintain such gigantic ventures such as running national airlines. There is a lot of theft, corruption, and mismanagement in public corporations in Africa which is due to political interference, and abuse of state assets by politicians.

\section{Monopolistic Competition}

Imperfect markets include monopoly, duopoly, oligopoly, monopolistic competition, monopsony, duopsony, and oligopsony.

\section{Advantages}

- Monopolies enjoy economies of scale which promote research and product improvement

- Monopolies such as state monopolies avoid competition and therefore they help reduce marketing and advertising costs

- Monopolies can plough back abnormal profits for expansion

- Monopolies undertake many Corporate Social Responsibility acts in Society

\section{Disadvantages}

- They reduce consumer power and consumer choice

- They exploit consumers due to information asymmetry

- Sub-standard goods and services may be supplied due to lack of competition and transparency

This is a market with some characteristics of monopoly over brands and some competition in terms of free market entry and exit, and having large number of players.

Players engage in non-price competition through product differentiation, advertising, and market segmentation. They set price

where $\mathrm{MR}=\mathrm{MC}$ and $\mathrm{AR}=\mathrm{AC}=\mathrm{D}=\mathrm{P}$

Services such as Restaurants, Hotels, stationers, grocery shops, florists, hardware, and dry cleaning outlets are all examples of enterprises in monopolistic competition. Firms in 
monopolistic competition also face different cost structures so their profit levels differ. They face a downward-sloping demand curve just like the monopolist.

The poultry industry started with a major differentiated product such as Tyson but later due to ease of entry and exit, others joined such as Perdue, Bell \& Evans, and Murray (Keat et al., 2015)

\section{Oligopoly}

An oligopoly is a market of few large firms which together can behave in collusion like a monopoly. Such markets exhibit price and non-price competition and in collusion, they form cartels, syndicates, and price- and quantity-fixing arrangements such as IATA, OPEC, and ACCA. (Keat et al., 2015)

Giant steel companies such as TATA, MITTAL and others are oligopolies which deal with monopolistic competitive automakers such as GM, Toyota, Nissan, Ford, and Mercedes Benz. In the USA, the beer industry shows oligopoly with firms such as Anheuser Busch (50\%), SABMiller) \& Molsen Coors (30\%), Heineken \& Stella Artois and InBev (Imports) (Keat et al., 2015)

Aircraft manufacturers such as Boeing, Airbus, Fokker, Lockheed, and British Aerospace are also oligopolies due to high entry cost to the aircraft manufacturing industry, and the need for advanced and sophisticated technology.

Farm machinery and equipment manufacturers such as John Deere, J.I. Case, and New Holland, Software developers of proprietary software such as Apple, Microsoft, and Intel constitute oligopolies in the USA (Keat et al, 2015).

\section{Contestable Markets}

A contestable market is a market with features just like perfect competition because even though there are few players, they behave as if they were in a perfect competitive market as there are no entry barriers.

\section{BACKGROUND OF ECG}

The generation, transmission, and distribution of power in Ghana is done by different entities including Volta River Authority (VRA), Independent Power Providers (IPPs)(Generation), GRIDCo (Transmission), Electric Company of Ghana (ECG), and Northern Electric Distribution Company (NEDCo) (Distribution) (See Appendices C, D, and E).

There are seven public entities involved with the electricity supply chain in Ghana namely the Ministry of Power, the Energy Commission, the Power Utility Regulatory Commission (PURC), Ghana Grid Company (GRIDCo), Volta River Authority, Electricity Company of Ghana (ECG), and Northern Electric Distribution Company (NEDCo), and Independent Power Providers (IPPs) in the private sector. The total potential output of Ghana is estimated at about 3325 Megawatts (See Appendix D; Kumi, 2017)

ECG is a wholly-owned government enterprise which is a limited liability company of the Government of Ghana and was incorporated under Companies Code 1963(Act 171) in February 1997 (ECG, History.online) It began operations in 1947 ten years before independence as a Department under the British Colonial Government. In 1962, it became known as the Electricity Division under the civil service. In 1967, under military rule, it became known as Electricity Corporation of Ghana under NLCD 123. In 1987, NEDCo was established 
to take over from ECG the distribution of electricity to the northern regions of Ghana (ECG, History.online)

\section{Sale of ECG}

According to ghanatrade.com (2016) the Millennium Development Authority (MiDA) will lead in the privatisation of ECG and it is likely a foreign investor would be brought in. The arrangement was made to enable the Ghana Government access a 500 million dollar loan facility from the MiDA Account in the USA. The Ghana Government had earlier on signed Compact 2 during the presidency of former President John Mahama (2012 to 2016) to enable Ghana access loans from the Millennium Challenge Corporation (MCC) so that ECG's operational efficiency would be enhanced and its losses reduced.

According to the outgoing US Ambassador to Ghana, Ambassador Jackson, ECG loses about eight ( 8 million) million dollars every week due to wastage and transmission losses (ghanatrade.com) as well as inefficient billing as it is asserted that billing rakes in only 65 per cent of expected revenue. The agreement for the sale of ECG to Manila Electric Company is for 20 years with existing employees guaranteed employment for the first five years (ghanatrade.com)

It is reckoned that the government of Ghana subsidizes electricity supply by as much as 160 million dollars. After the sale of ECG, the Government of Ghana will retain 51 per cent equity shares with Manila Electric Company having 49 per cent. This is a Joint Venture Partnership (JVP) along the model of Build, Operate, Transfer, and Lease (BOTL) and Public Private Partnership (PPP) models to enable Ghana get the best of both worlds in terms of ownership, expertise, and technology transfer, access to capital, and guarantee of jobs for locals (ghanatrade.com).

The Compact 2 seems to consider diversity, inclusiveness and moral and ethical issues by creating space for local employees to be retained. It is often traumatic in most cases for many employees who happen to be part of an entity undergoing divestiture, takeover, and merger as they are thrown in the cold if they are not given ample notice to adjust to changes.

Such hard-landing separation should be avoided as employees who are to be discharged can be given good packages or be made as partners or equipped with exit strategy such as Future Search entrepreneurial skills and a form of rehabilitation. That is more ethical and a holistic approach to divestiture and change management. In most cases, such employees tend to be caught unprepared and are given little time for adjustment as many are unaware of their rights in such circumstances.

According to Hein \& Co (1972) from 1947 to 1972, Ghana imported the legal form of Public Corporation from its former colonial master, Britain. Hein asserted that Public Corporation is midway between a government ministry (civil service) and a private company hence it is a hybrid form of business.

\section{LITERATURE REVIEW OF PUBLIC CORPORATIONS}

Nhema (2015:) contends that privatisation of state enterprises in the past three decades has become a trend in order to deregulate government role and create more space for private enterprise to flourish, especially in the developing countries. Nhema (2015) asserts that this is to end state monopolies which are epitomized by corruption and incompetence. Nhema (2015) views privatisation as sale of government-owned enterprises to the private sector in order to make them more transparent, efficient and competitive. 
However, one size does not fit all because on the developmental time scale, African countries have come from socialist dispensations where they enjoyed freebies and practised eleemosynary economics of governments dispensing subsidies, government largesse, and there was therefore a big vacuum of an entrepreneurship class in Africa which would step into the big shoes left behind by the divestiture and liquidation of assets of state enterprises.

The sad and sorry scenario is that the few ruling African elite in power are the only ones with the wherewithal to stake equity shares in those sold state enterprises, thus not fulfilling the conditions for Pareto optimality as the majority poor get poorer and the minority rich get richer. Invariably, the sale of state enterprises through the austerity measures of the 80s and 90 s led to mass pauperization of many African workers and their numerous dependants.

Nhema (2015) defines privatization as the transfer of ownership and control of state enterprises into the private sector domain by sale through the capital markets which are mostly underdeveloped in Africa (Nhema, 2015:1). Richard, Mansoor, \& Ali (1988) cited in Nhema (2015:1) distinguished between divestiture which is an outright sale of a (going concern) public corporation on the one hand, and a liquidation which is the sale of a lossmaking public utility on the other hand in order to pay debtors.

In the case of the sale of ECG, it is a Joint Venture Capital arrangement with the Ghana Government retaining 51 per cent equity shares for the Ghanaian public and the Manila Electric Company (Meralco) having 49 per cent. This is equitable and ethical in the sense that the agreement gives Meralco leverage for 20 years to infuse new capital and technology in ECG and also manage it efficiently to reduce the leakages in the system. Public corporations are utilities such as transportation, water, electricity, telecommunications, financial institutions such as banks, bourses, insurance companies, and research institutions, among others.

Many are bedevilled by heavy deficits, mismanagement, revenue losses, inefficiency and incompetence and are the running sore or festering open sore of government. Public utilities are financed by tax revenues, loans, hardly by internally and government subsidies and grants (Nhema 2015:1) In Africa, most state-owned enterprises are perceived to be conduit pipes for siphoning state revenue into the pockets of political party appointees and party cadres.

The Washington Consensus view them as public drains on state resources and therefore the World Bank and IMF in the 80s and 90s recommended Structural Adjustment Programmes (SAPs) and Enterprise Reform Programmes (ERPs) for many Highly- Indebted Poor Countries (HIPC) in Africa. Those programmes imposed severe hardships on Africans as some of the programmes were said not to have a human face.

However, they were creditors and they wanted their money back so the saying goes, 'he who calls the piper, pays for the tune'. Sadly enough, many citizens and stakeholders were not consulted by their leaders when contracting external loans which were used to finance the state-owned enterprises and utilities. This therefore calls for transparency and accountability in a democratic dispensation.

There is need for African leaders to engage the citizens in Dialogue, Ubuntu, and Nsaka so that they refrain from being tin gods and dictators. Public utilities such as ECG need to be offloaded unto the market to bring about closure, inclusivity, and diversity through broader participation in the decision making arena. There is need for infusing good governance in the public corporations by borrowing best practices from the private sector to help make the state-owned 
enterprises sustainable. The corporations have been debt-ridden due to greed, insider-trading, and cronyism.

World Bank (1983); Nellis \& Kikeri (1989:569) cited in Nhema (2015:1) affirmed that globally, public enterprises contribute 10 per cent of GDP at factor cost; and for Africa, it is 20 per cent with Ghana and Zambia clocking highs of 38 per cent (Obadan, 2008 cited in Nzema, 2015:2) which figures show how weak and abused our public corporations are.

Furthermore, they observe that a big chunk of external debt of the poor developing countries is attributed to the poor performing public utilities hence the incessant calls by creditors for their sale or offloading into the private sector.

Nhema (2015:2) observed that from 1979 to 1990, privatisation gained momentum in Africa due to external pressures. Zambia has been under big pressure to sell ZESCO, the power utility but this has not been officially acknowledged by the government despite many rumours that the power utility has been silently sold.

The Zambian Minister of Finance, Hon. Margaret Mwanakatwe, has publicly denied the rumour of the sale of ZESCO.

In the UK, the then Prime Minister, Margaret Thatcher, accelerated the sale of many British public enterprises including British Steel, Gas, and Telecoms, among many others through state intervention or state visible hand under the New Economic Order (Nhema, 2015:2). The move was to reduce the heavy state burden and also the heavy debt burden placed on the national kitty by the albatross public utilities. African countries at independence embarked on many state-engineered development plans to accelerate economic growth and boost industrialisation hence the creation of many state-owned enterprises.

They saw massive state-owned enterprises as special purpose vehicles to implement their agenda. Sadly enough, those state enterprises became like poorly fed cash cows that were milked but grudgingly fed on scraps. Thus by the 1990s, those state enterprises set up in the $60 \mathrm{~s}$ and $70 \mathrm{~s}$ had begun to wane in their fortunes as the euphoria of political independence wore off and people began to become realistic and rational.

The donors and foreign financiers began to decry the rot in the state-owned enterprises (Nhema 2015:2), and they recommended denationalisation, deregulation, public sector reform, restructuring, privatisation and a resort to market-based economy. Some African scholars and observers saw calls for privatisation as a form of recourse to a new wave of slavery, which some have dubbed 'Digital Slavery'. Of course there is the principle of quid pro quo (nothing goes for nothing).

According to Walle \& Harden (1989) cited in Nhema (2015:2) the existence of missing markets for merit and public goods and also market failure led to the establishment of State-Owned Enterprises to help redistribute incomes, provide public infrastructure, impose price controls, and assist in creating jobs. However, government intervention later led to government capture, market and government failure, and increase in the widening of the gap between the rich and poor. (Hemming \& Mansoor, 1988; Todaro 1989; Wall 1989; Djik, 1994) cited in Nhema (2015:3) 
Furthermore, academics believe that market intervention by government leads to crowding out effect on private sector enterprises as they cannot compete with government in economic space.

Nhema (2015:3) postulates that government intervention in economic space creates indifference among directors and CEOs of state-owned enterprises who have no financial incentive to husband resources carefully because they have financial stake in the enterprises they lord over.

All they care for are the juicy perquisites which go with their political appointments to the boards of such parastatals or SOEs. Nhema (2015) posits that the reason why parastatals do less in performance compared to their private sector counterparts is because the oversight function is weaker in the former than in the latter due to weak levels of corporate governance and also having no linkage of appointment to ownership, control structure, and performance metrics or KPIs (Key Performance Indicators) or CSFs (Critical Success Factors).

This has unfortunately led to many CEOs who are appointed by government to indulge in a syndrome of 'enter, loot, and share'. Kenya's Kenya Tea Development Authority is one success story of privatisation in Africa (Nhema, 2015:3) because it is observed that the entity allowed critical stakeholders, the tea growers, to sit on the board. Outside Africa, Sweden recorded a success story when Statsforetag was fragmented and sold to the private sector.

That was not the case in India where in the 1970s the breakup of Fertilizer Corporation of India did not post any success story because according to Ayub \& Hegstad (1987) cited in Nzema (2015) the context did not change even though the content did. Lukje (1988) cited in Nzema (2015) chronicled massive failure of privatisation in Senegal. Aristotle and St Augustine decried state ownership in their treatises even though Plato supported state ownership of businesses.

According to Aristotle and Augustine, public property has no owner because it is an orphan that is abused. Buchanan \& Tullock (1962); Mueller (2003) cited in Nhema (2015) looked unfavourably on state enterprises as erratic and unsustainable models which often led to government failure, state capture, and eventually market failure.

In Ghana, about 38 per cent of the economy is state controlled, hence leading to massive wastage of state resources due to incompetence, over-bureaucratisation of state enterprises such as ECG, insider trading, and political patronage. Such unfortunate practices have led to ballooning of the national debt which currently stands at $\$ 34$ billion dollars or 58 per cent of GDP.

This sad scenario has been attributed to the winner-takes-all syndrome in our political dispensation due to weak checks and balances in national governance. There is need to be robust with Montesquieu's and de Tocqueville's theory of Separation of powers by having a reform of Ghana's 1992 Constitution which tilts the power balance in favour of the Executive arm of government. According to Obadan (2008); Paul (1985); Samuel (1999) cited in Nhema (2015), government is saddled with too much bureaucracy as to make proper use of borrowed money to manage the public utilities.

This stance is also supported by Nellis (1986:11) cited in Nhema (2015:5) According to Nhema (2015:6) external donor pressure for reform of public enterprises has since the 1980s been the 
driver of privatisation in Ghana in particular and Africa in general. The pressure is mostly from the Washington Consensus which is made up of the IMF and the World Bank.

However, these giant multilateral institutions have been taken on aggressively by debtors for prescribing panacea which do not fit the bill for African countries because their prescriptions lacked a human face, and they have since changed ways by working cooperatively and collaboratively with recipient countries. However, many critics have chastised the donors for double dealing as their aid has often been seen as fungible and improperly administered because of lack of local capacity to absorb and administer aid money, leading to the cliché, Dead Aid which was coined by Dembisa Moyo.

There is therefore need to deepen local entrepreneurship knowledge base and also need to deploy ICT facilities to monitor disbursement of aid money. There is need to train and educate CEOs on corporate governance tenets such as are found under COSO, The Combined Code, INTOSAI, London Stock Exchange Guidelines, and the Sarbanes -Oxley Act of 2002. QuasiGovernmental Organisations (QUANGOS) such as the Internal Revenue Authorities, Customs and Immigration, ECG, Ghana Water and Sewerage Company Limited and Civil Aviation Authorities need to be closely monitored to prevent theft and leakages of their revenues.

Zhou (2001) cited in Nhema (2015:7) suggested removal of strangleholds on public utilities by de-bureaucratizing them so that there can be massive inflow of Foreign Direct Investment (FDIs). The success of privatisation has been chronicled by Megginson \& Netter (2001); Obadan (2008); Kikeri et al.,(1994); Perevalow (1999) cited in Nhema (2015) who all agreed on the overall success of privatisation globally.

However, empirical research needs to be carried out to establish the social, ethical, cultural and human rights cost dimensions of such an exercise as the human suffering attributed to privatisation may far outweigh the financial gains from privatisation. Russia has been cited as one country where privatisation was not very successful because the exercise ended up empowering a few Russians in the oligarchy (Cook \& Kirkpatrick, 1988) cited in Nhema (2015:8)

The Ghana Ministry of Finance Report of 2017 stated that 45 enterprises were wholly owned by government with another 41 of them being Joint Venture Capital (JVC) making a total of 86 state-owned enterprises. The debt to GDP ratio in Ghana in 2016 was $73.1 \%$ but this has been revised in 2019 to $58 \%$. Majority of this debt is owned by the state-owned enterprises which have been used by some unpatriotic politicians to line their pockets and to appease political cadres by rewarding them with appointments to boards of such enterprises.

To rationalise their operations, a single umbrella body has been set up by government known as State Interests Ghana Authority (SIGA) whose equivalent in Zambia is the Industrial Development Corporation (IDC).

These bodies had their equivalents long ago in the immediate post-independence era such as GIHOC (Ghana Industrial Holdings Corporation) and MEMACO in Zambia. The new umbrella bodies will oversee the operations of these fragmented state enterprises. However, this is seen as business as usual as such bodies often are ineffective and are used as means to create jobs for government appointees, thus this can be viewed as an exercise in futility.

The Report (MOF, 2017:45) indicates that the Auditor General has set up Action Plans to seal the gaps in various state-owned enterprises in Ghana including ECG, VRA, GWCL, GNPC, TDC, 
and SEC. It is this author's opinion that there are too many operators in the public arena such that it is difficult to apportion blame whenever anything goes wrong.

This is Ghana for you. Ghana needs a radical shake-up by having a bold leader who will reengineer the system through constitutional reform and also change the mind-set of Ghanaians to be less selfish and more patriotic. Morals have degenerated as people have been fixated on acquisition of ill-gotten wealth through get-rich-quick methods, by fair or foul means.

The moral decay is so much so that Niccolo Machiavelli would be seen by many Ghanaians today as a hero rather than a villain. Top employees of state enterprises have no performance agreements with the Ghana government on their performance targets or deliverables because there is a plethora of oversight bodies and as such, they are made ineffective.

The Energy sector in Ghana has the highest cost of all state-owned enterprises in Ghana, hence the need to offload ECG (MOF, 2017). According to the Report (2017:13) ECG was highly geared with low liquidity and it was unable to meet its current liabilities. Besides, it did not adhere strictly to audit and performance compliance. Its strategic direction was unclear and it lacked competence for future expansion.

Mahmoud (n.d.,:16) observed that SOEs were set up to widen ownership base and generate revenues for government but in Ghana and in Zambia, SOEs have been milked as cash cows by a few people in power and top managers of those enterprises who have political linkage to the corridors of power because they owe their appointments to the powers-that- be.

Mahmoud asserted that wide budget deficits in developing countries are as a result of subsidizing loss-making state enterprises. Mahmoud chronicles privatisation success in South Africa, Singapore, UK and other countries, stating that in the USA privatisation was extended to refuse collection, prison services, road repair, railroads, and petroleum reserves, among other enterprises.

This American model however, in the view of this author, is the extreme of capitalism or the free market economy because privatising prisons and national security services has its national security, moral, social, and ethical implications. If that is the case, then there is no need to have a central government in place because there are activities such as prison services and state security which should remain centralised, as outsourcing those services to private providers could lead to vindictiveness, social instability, and national insecurity.

Some services are constitutional imperatives for central government. The American model should not be replicated hook, line, and sinker everywhere in the world because each country has its own cultural, contextual, and political nuances. Capitalism cannot solve all human problems, hence the existence of missing markets, market failures and government failure.

Mahmoud (n.d.,:11) bemoaned the lack of developed capital markets in Africa and also not matching marginal social benefits(MSB) with marginal social costs (MSC). He further lamented not creating enabling environments to attract foreign investors (Mahmoud, n.d.,:10-11)

Appiah-Kubi (2001) posited that between 1987 to 1999 SOEs in Ghana generated 14\% of GDP. He observed that the sale of some SOEs raised socio-political issues of not observing distributive justice, fairness, accountability and sustainability. He observed that the sold enterprises could not generate high revenues because the Ghanaian economy has not matured 
enough and also that the sold enterprises were debt-ridden and had been over-regulated. This writer concurs in toto with Appiah-Kubi's insightful observations.

Adda (n.d.;1) observed that for SOEs not to pursue market objectives, they become lossleaders and uncompetitive. That was why in the UK Margaret Thatcher sold British Steel, British Aerospace, British Airways, Rolls-Royce, British Gas, British Telecom, British Coal and British Rail.

1. What is ECG?

\section{RESEARCH QUESTIONS}

2. Why is ECG being sold?

3. Are Ghanaians aware of the contextual circumstances leading to the sale of ECG?

4. What will be the benefits to Ghanaians of selling ECG?

5. Is privatisation of State-owned enterprises the only option?

1. To provide a profile of ECG

2. To explore the narrative on the reasons for privatisation of state-owned enterprises

3. To provide evidence that explains why ECG is being sold

4. To examine success stories of privatised state-owned enterprises

5. To examine options involved in privatisation of state-owned enterprises

\section{PROBLEM STATEMENT}

The Electricity Company of Ghana (ECG) has undergone many transitions and it is one of the prime state assets which was so visible and essential to every Ghanaian. As such, any news about the reform of ECG attracts a lot of attention in the media. Many businesses in the private sector depend on services provided by ECG for their livelihood. The entity provides both direct and indirect services and employment to many Ghanaians and residents.

It is planned that from $1^{\text {st }}$ February 2019, ECG will be managed by a foreign consortium led by a Philippino company, Manila Electricity Company (Meralco) as part of a compact signed between the Ghana Government and the USA-based Millennium Challenge Account (MCC) and Millennium Development Agency (MiDA) The demand for electricity everywhere in the world is inelastic because there are few substitute alternatives such as solar, biogas, and geothermal energy which many cannot afford. Thus ECG is a virtual natural monopoly in Ghana.

Electricity tariff increases therefore have great knock-on effect on all domestic and industrial activities in Ghana. Being a virtual monopoly, it has not been competitive and efficient in supplying power to consumers who sometimes have to go several hours or days without electricity, and this has adverse effects on productivity, GDP, international tourism, Foreign Direct Investment, and generally the standards and quality of life of citizens of Ghana, hence this topic being of great significance to the author and most of all, stakeholders.

\section{SIGNIFICANCE OF THE STUDY}

The crisis of power supply in Ghana captured the attention of the international media a couple of years ago, precisely from 2013 to 2015 when severe power supply shortages caused a lot of inconvenience in Ghana. The issue was heavily politicised and the then ruling National Democratic Congress party was dubbed as incompetent.

The Ghana Government therefore sought many interventions including procuring a power barge and increasing and diversifying power supply sources to include thermal, solar, and 
hydro-electricity. This research paper will provide a lot of evidence on the power capacity of Ghana, and will help enlighten many citizens who are not aware of the hard facts on the ground. It will be useful to future researchers, students, and foreign investors who need information on investment opportunities.

\section{LIMITATIONS AND SCOPE OF THE RESEARCH}

This paper is limited in scope as to length and the scope of coverage. The author would have loved to explore best practices around the globe to make the work empirical but time constraint as well as word count limit make it hard to delve deeper.

\section{METHODOLOGY}

The approach adopted in this paper is qualitative and descriptive as it is a review of existing literature to gain insights and to help make recommendations and informed judgments.

\section{ETHICS OF RESEARCH AND DIVERSITY}

There is a lot of political vibration in Ghana over many issues including the sale of ECG. The author will adopt an apolitical stance by being neutral and objective. Furthermore, the author will continuously acknowledge sources of information used in the research in accordance with the APA style of citation, academic writing and appropriate referencing style.

This will be done to avoid issues of plagiarism or not duly acknowledging secondary sources used in the research. Furthermore, a critical style of writing will be used by being mindful of the needs, emotions, and feelings of readers. The author will also adopt a balanced style of writing by examining both sides of an argument in order to bring closure and inclusivity to reflect cultural diversity, and a holistic approach.

\section{FINDINGS AND ANALYSIS}

Appendix A shows the map of Ghana with 10 regions with an estimated population of 30 million and a land area of 238,535 square kilometres (CIA World Facts 2018; worldometres.com) Ghana currently has a population density of 120 people per square kilometre, which happens to be on the higher side compared to a country such as Zambia with a density of 21 people per square kilometre, six times less than Ghana's.

The import of this is that there is a higher demand for electricity in Ghana more than in Zambia hence there is more investment opportunity in the energy sector in Ghana. The high density of population in Ghana also calls for utilisation of more and cheaper energy sources such as biogas, solar power, geothermal energy, tidal power, wind power, uranium or nuclear energy, and ethanol. The current ruling NPP Government has created six more regions or administrative regions in February 2019 in order to increase political participation and to accelerate economic growth in all parts of the country.

This latest new development will make greater demands on the energy sector particularly, on the generators and distributors of power in Ghana such as ECG and VRA. Critics of the Ghanaian Government think that this move to create an additional six regions is not wellintended as it will lead to balkanization of the country and fragmentation of utility services. Be that as it may, the decision for the creation of new additional regions was arrived at constitutionally and it followed due process of holding referenda and receiving petitions from the interested parties.

Ghana has a coastline of 560 kilometres on the Gulf of Guinea on the Atlantic Ocean. There is therefore great potential to tap tidal power from the sea as it is done in Israel. 
The sea can also offer opportunities for tapping wind power as well as solar power. With oil production on stream along the western coast of Ghana, what is required is to increase efficiency, transparency, and effectiveness in the way the oil revenue is managed and utilized to benefit Ghanaians, with regard to the Sovereign Fund which was set up to ring-fence oil royalty revenues and proceeds. Oil production also comes with the opportunity of utilising the efficient and cheaper gas which is often flared off and wasted.

Appendix B. depicts the Supply Chain which begins with power generation, transmission, distribution, and ends with the end-users, the consumers who are made up of importers of power, domestic consumers, commercial and industrial consumers, government and institutional consumers, and other users.

More often than not, government ministries and outfits have been heavily indebted to those power distributors such as ECG and NEDCo at the very end of the supply chain. Also there have been thefts by private consumers who are engaged in illegal electrical connections. This is possible due to poor numbering of streets, alleys and housing units in Ghana, and poor human settlement planning as housing plans are ill-regulated due to indiscipline, high levels of bribery and corruption, and low levels of law enforcement.

At the electricity generation stage, the government has liberalized power generation by bringing in both local and foreign companies to compete with the giants in the field such as the Volta River Authority (VRA) at Akosombo in Ghana, the owners of the giant Hydro-Electricity Dam. The heavy investment required and the high level of technology required to set up in power generation has thinned out the field, thus creating virtual oligopoly and monopoly.

The market share of the Independent Power Providers (IPP) is indeed minimal as shown by Appendix C whereby VRA (Akosombo Dam) alone produces 1,020 Megawatts or 44\% out of the total installed capacity of about 3300 Megawatts. The demand for electricity grows exponentially in Ghana as there is a bulge in the middle class, and as majority of the youthful population have taken to the use of ICP products such as computers and smart phones.

The middle class is growing rapidly as many people are becoming entrepreneurial, sophisticated and well educated. The government recently embarked on a free Senior Secondary School programme to provide free progression into senior secondary school from the Junior Secondary School. Critics of the system of power distribution in Ghana question the rationale behind exporting power to neighbouring countries such as Togo, Benin, and Burkina Faso while sectors of the local population are not connected to the national grid.

According to Kumi (2017) about $82.5 \%$ of Ghana's population have access to electricity and the demand for electricity grows ahead of supply. Kumi (2017) recommends diversification of the energy sector to include renewable sources of energy such as wind, solar, tidal and geothermal. The use of natural gas by vehicles in Ghana has been around for upwards of about 20 years now, and many drivers have recommended its use for its low cost and environmental friendliness.

With the announcements last year that world class corporations such as Siemens, Nissan, and VW will establish plants in Ghana, there is need to increase installed electrical capacity to meet the needs of these industry giants.

Appendices D, E, and F show the number of players found in the supply chain of electricity in Ghana, which to all intents and purposes shows a sign of duplication, confusion, and chaos. 
There are far too many regulators, institutions, and think-tanks on the ground, as observers believe that this has been so because of the need of the politicians to find avenues to create jobs for their patrons and loyalists.

This does not bode well for efficient administration and management of state assets. The policy making body on energy in Ghana is the Ministry of Power while the advisory, monitoring, and planning body is the Energy Commission. In some rich countries, these functions of policy, advisory, monitoring, and planning would have been merged into one body as the Ministry of Energy, where bureaucrats, technocrats, and administrators would sit under the same roof.

PURC is the Public Utilities Regulatory Commission which advises or sanctions suggestions for electricity tariff increases. This body which is supposed to be independent is often in the pocket of the government because its members are appointed by government. This body should rather be rotating like a jury which is ad hoc. The role of the Volta River Authority is non-controversial as they are the owners of the hydro-electric dams such as the Akosombo, Kpong, and Bui Hydro-Electric Power (H.E.P.) stations. They are engaged in the technical job of power generation, with a few small-scale Independent Power Providers (I.P.P.s) chipping in with supplements of solar, thermal, and gas sources of power.

It is hoped these SMEs will help diversify the sources of power and that with time they will grow big to challenge the market monopoly of the giant players, with the benefits translating to lower tariffs for consumers. Thus the government of Ghana has to create a level playing field, and a conducive environment to attract foreign investors, and also to enable private providers thrive. Power transmission in Ghana is solely by GRIDCo as transmission is a highly technical field.

However, before GRIDCo was formed as an intermediary in the supply chain, generation and transmission were done by VRA and ECG respectively. Much as specialisation in the energy supply chain is appreciated, having a long chain of suppliers or providers in the upstream, midstream, and downstream sections of the supply chain unnecessarily increases cost of services to the final consumer. Thus Ghana may lose competition to countries with comparatively cheaper power tariffs.

Finally, it is imperative for the players in the supply chain to seek tight forward, horizontal, lateral and vertical integration in the supply chain to reduce costs and to pass on the gains of economies of scale and scope to the final consumer. In that way, Ghana can gain an upper hand over other investment destinations as a country with competitive advantage for attracting Foreign Direct Investment (FDI)

\section{CONCLUSIONS}

In conclusion, it is clear that public utilities are a drain on scarce public resources because of incompetence and political interference. However, privatisation has not been all that rosy either, because of poorly developed capital markets and lack of entrepreneurial and negotiation skills in many African countries, Ghana being no exception.

The sale of ECG by $1^{\text {st }}$ February 2019 is on point but the experience of other countries' success stories in Kenya, Sweden, Singapore, and South Africa could be enlightening to the Government of Ghana as well as to other African countries such as Zambia where rumours are rife that the state power utility, ZESCO has been either sold or about to be sold the Chinese to whom there is a great deal of indebtedness due to perceived excessive public bilateral borrowing. 


\section{RECOMMENDATIONS}

- It is recommended that the sale of ECG should involve extensive dialogue with all stakeholders by communicating to them the benefits and also educating them on the dire need to sell off ECG

- All sales of state enterprises should be conducted in ethical and transparent manner

- The sale of State enterprises should be conducted with thorough circumspection as foreign models should not be copied wholesale because of each country's peculiar historical, social, and economic contextual factors

\section{References}

Adda, W.A., (n.d.) Privatisation in Ghana's Public Enterprise Reform Programme [Online]

Appiah-Kubi, K. (2001) State Owned Enterprises and Privatisation in Ghana The Journal of Modern African Studies, Vol. 39, No. 2, 2001, Cambridge University Press

Baye, M. (2010) Managerial Economics and Business Strategy, (7th ed.). Boston: McGraw-Hill Irwin

Beardshaw, J., Brewster, D., Cormick, P. \& Ross, A (2001) Economics- A Student's Guide Harlow, England: FT Prentice Hall (p. 37 and pp. 348-350)

Begg, D., Vernasca, G., Fischer, S. \& Dornbusch, R. (2013) Economics Maidenhead, Berkshire: McGraw Hill (pp. 166188)

Begg, D., Vernasca, G., Fischer, S. \& Dornbusch, R. (2011) Economics Maidenhead, Berkshire: McGraw Hill (pp.144169)

Business Dictionary Economic Efficiency (n.d.) [Online] Retrieved from http://www.businessdictionary.com/definition/economic-efficiency.html

CIA World Facts (2018) Ghana

Frank, K.H. \& Bernanke, B.S. (2007) Principles of Economics New Delhi: Tata McGraw Hill Publishing Company Limited (pp.288-289)

Froeb, L. M. and McCann, B. T. (2009) Managerial Economics: A Problem-Solving Approach, (2nd ed.) Boston: Cengage Learning EMEA.

Ghana (2012) Report of the Auditor General on Public Accounts of Ghana-Public Boards, Corporations and other Statutory and other Institutions for the Year Ended 31st December, 2012

Gough, J. (2000) Introductory Economics for Business and Management. New York, N.Y: McGraw-Hill

Grant, S.J. (2008) Stanlake's Introductory Economics Harlow, Essex: Pearson Education

Hayes, A. (n.d.) Economics Basics: Supply and Demand [Online] Retrieved from https://www.investopedia.com/university/economics/economics3.asp

Investopedia (n.d.) Sensitivity Analysis [Online] Retrieved from https://www.investopedia.com/terms/s/sensitivityanalysis.asp

Keat, P.G., Young, P.K.Y. \& Erfle, S.E. (2013) Managerial Economics (7th ed.) London: Pearson Education

Kumi, E.N. (2017) The Electricity Situation in Ghana: Challenges and Opportunities [Online] Centre for Global Development, University of Energy and Natural Resources, Sunyani, Ghana Retrieved from https://www.cgdev.org/sites/default/files/electricity-situation-ghana-challenges-and-opportunities.pdf

Lipsey, R. \& Chrystal, A. (2010) Economics (12th ed.) Oxford: Oxford University Press (pp. 123-140)

Mahmoud, M.F. (n.d.) Privatisation: A Solution to Problems of Public Enterprises. Department of Public Administration, College of Administrative Science, King Saud University, Riyadh, Saudi Arabia

Mankiw, N.G. (2008) Principles of Economics London: Cengage Learning (pp. 258-277)

Ministry of Finance Report, Ghana (2017) State Ownership Report

Nhema, A.G. (2015) Privatisation of Public Enterprises in Developing Countries: An Overview International Journal of Humanities and Social Sciences Vol. 5, No. 9, September 2015

Peterson H.C and Lewis W.C (1999) Managerial Economics $4^{\text {th }}$ Edition Upper Saddle River, New Jersey 07458 USA 
Pindyck, R. S. and Rubinfeld, D. L. (2013) Microeconomics (International Edition, 8th ed.). London: Prentice Hall Salvatore, D. (2014) Managerial Economics in a Global Economy (8 $8^{\text {th }}$ ed.) Oxford: Oxford University Press

Sloman, T. \& Garratt, D. (2010) Essentials of Economics (5th ed.) Harlow, Essex: Pearson

Study.com (n.d.) Relevant \& Irrelevant Costs Definitions \& Examples [Online] Retrieved from https://study.com/academy/lesson/relevant-irrelevant-costs-definitions-examples.html

Watkins, T. (n.d.) Comparative Statics Analysis [Online] Retrieved from http://www.appletmagic.com/compstat.htm Education (pp.85-96)

Witztum, A. (2005) Economics - An Analytical Introduction Oxford: Oxford University Press (pp. 102-153)

Worldometers Ghana's Population http://www.worldometers.info/world-population/ghana-population/

\section{APPENDICES}

\section{Appendix A Map of Ghana showing the ten regions and capitals}

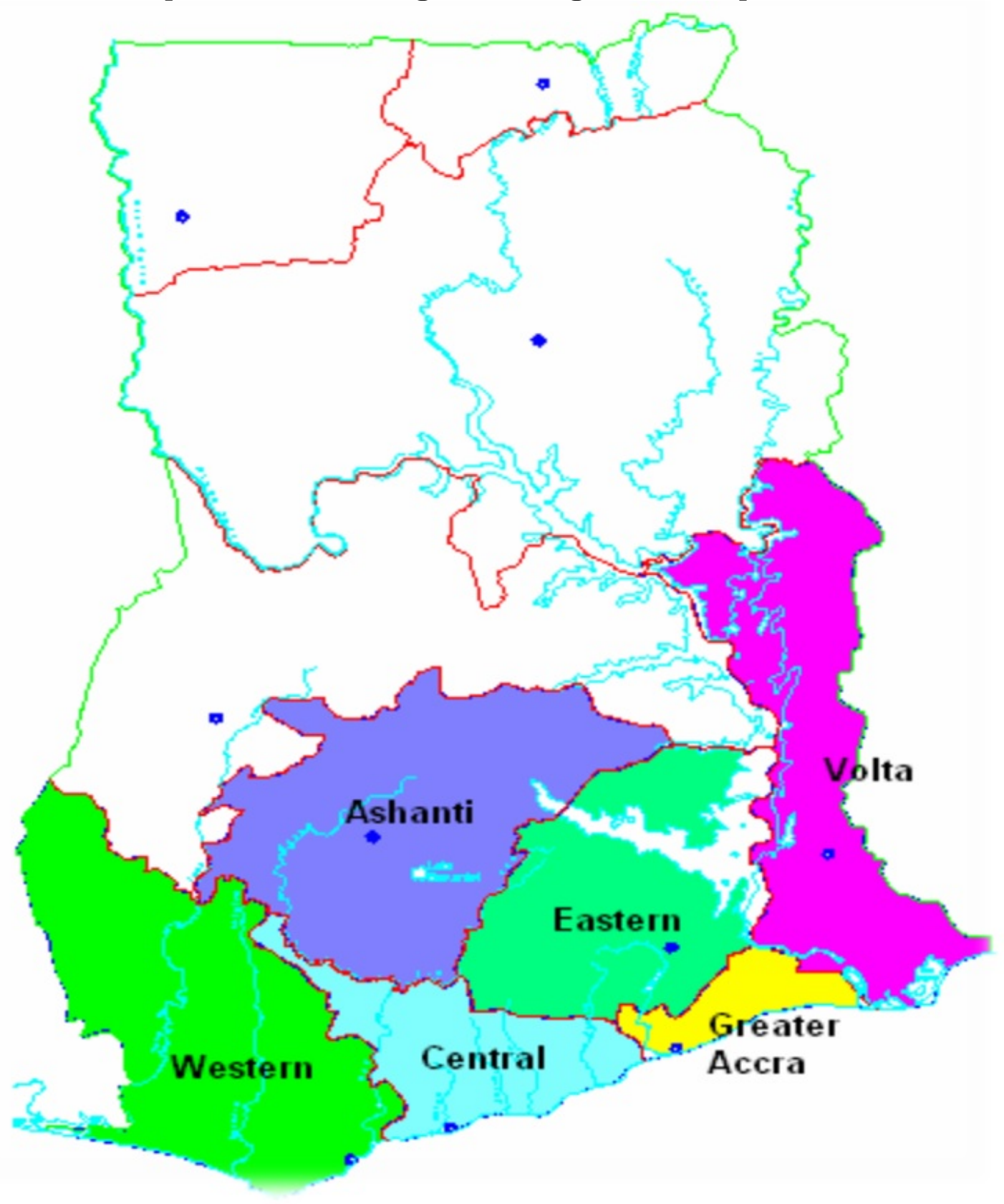

Source: http://www.ecgonline.info/index.php/about-the-power-sector-in-ghana.html 


\section{Appendix B Supply Chain of Electric Power in Ghana}

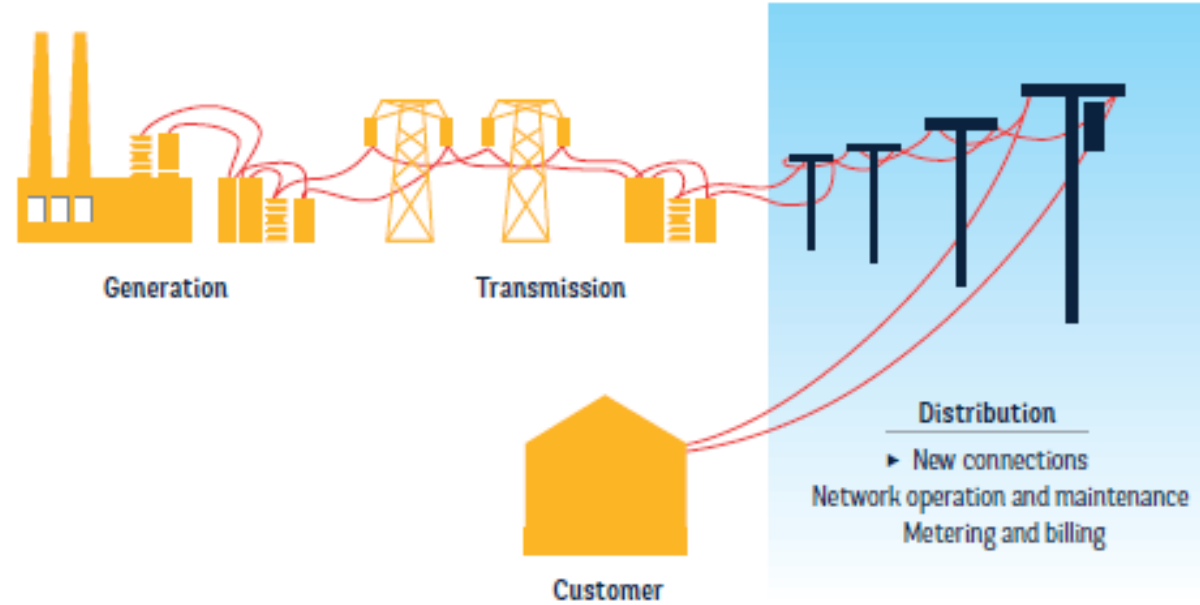

Source: http://www.ecgonline.info/index.php/about-the-power-sector-in-ghana.html

\section{Appendix C Installed capacity of power output in Ghana}

\begin{tabular}{|c|c|}
\hline Generation Facility & Installed Capacity (MW) \\
\hline Akosom bo Hydroelectric Power Plant & 1,020 \\
\hline Kpong Hydroelectric Power Plant & 160 \\
\hline Takoradi Thermal Power Station (T1) & 330 \\
\hline Takoradi Thermal Power Station (T3) & 132 \\
\hline Takoradi International Company (TICO/ T2) & 220 \\
\hline Tema Thermal 1 Power Plant & 110 \\
\hline Tema Thermal 2 Power Plant & 50 \\
\hline Mines Reserve Power Plant & 80 \\
\hline Solar Power Plant & 2.5 \\
\hline Sunon-Asogli Power Plant (SAPP)* & 200 \\
\hline CENIT* & 126 \\
\hline Bui Hydroelectric Power Plant & 400 \\
\hline Karpower* & 225 \\
\hline Ameri* & 250 \\
\hline BXC Solar PV Plant & 20 \\
\hline
\end{tabular}

Source: $\underline{\text { http://www.ecgonline.info/index.php/about-the-power-sector-in-ghana.html }}$ 
Appendix D Players in the power industry nexus in Ghana

\begin{tabular}{ll} 
INSTITUTION & MAIN FUNCTION \\
\hline Ministry of Power & $\begin{array}{l}\text { Government mouthpiece and responsible for energy } \\
\text { policy formulation }\end{array}$ \\
\hline Energy Commission & $\begin{array}{l}\text { Energy Policy Advisory, planning, technical regulation \& } \\
\text { monitoring. }\end{array}$ \\
\hline PURC & Electricity Tariff Regulation \\
VRA & Electricity Generation \\
GridCo & Electricity Transmission \\
\hline ECG & Electricity Distribution (Southem Sector) \\
NED & Electricity Distribution (Northem Sector) \\
Energy Foundation & Promotion of energy efficiency and conservation \\
\hline IPPs & Electricity Generation \\
\hline
\end{tabular}

Source: $\underline{\text { http://www.ecgonline.info/index.php/about-the-power-sector-in-ghana.html }}$

Appendix E Players and their roles in the power industry in Ghana

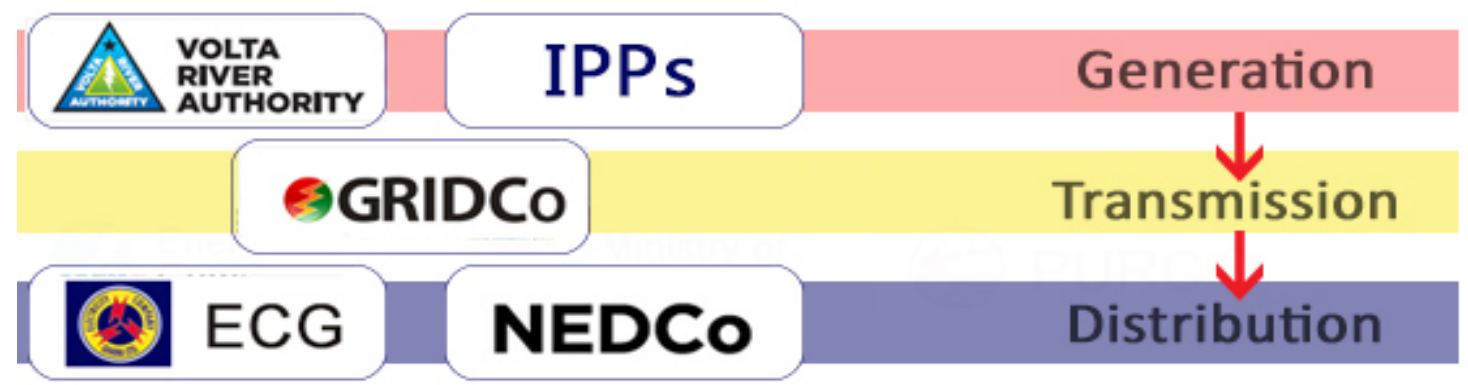

Source: http://www.ecgonline.info/index.php/about-the-power-sector-in-ghana.html

Appendix F Producers and consumers of power in Ghana
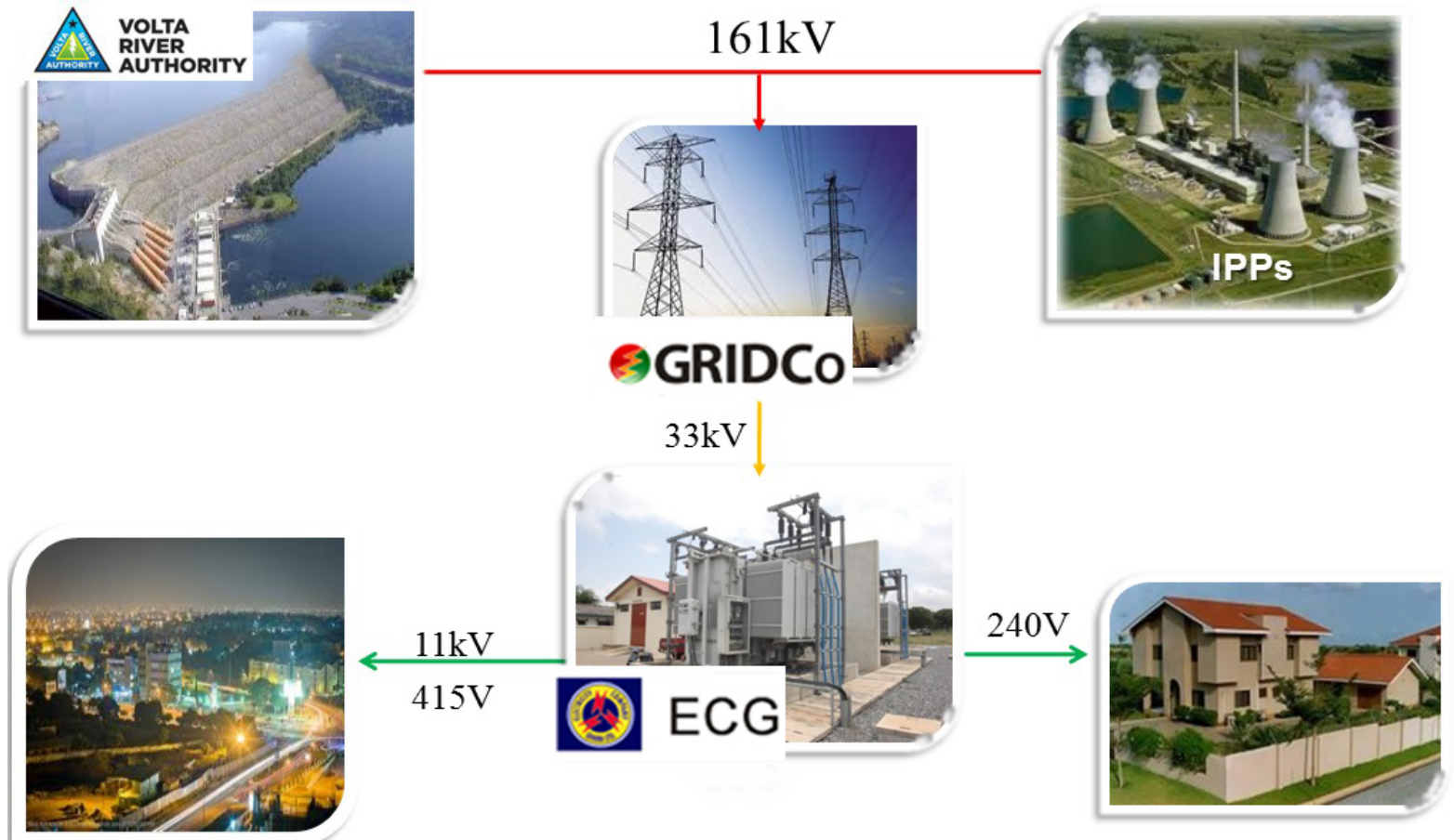

Source: http://www.ecgonline.info/index.php/about-the-power-sector-in-ghana.html 